\title{
Article \\ Cattle Manure Fermented with Biochar and Humic Substances Improve the Crop Biomass, Microbiological Properties and Nutrient Status of Soil
}

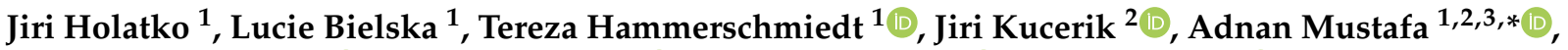

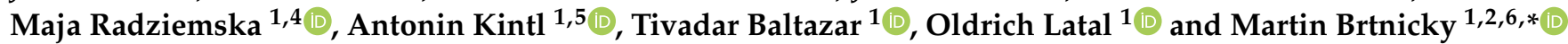

1 Department of Agrochemistry, Soil Science, Microbiology and Plant Nutrition, Faculty of AgriSciences, Mendel University in Brno, 61300 Brno, Czech Republic; jiri.holatko@mendelu.cz (J.H.); lucie.bielska@mendelu.cz (L.B.); tereza.hammerschmiedt@mendelu.cz (T.H.); maja_radziemska@sggw.edu.pl (M.R.); kintl@vupt.cz (A.K.); tivadar.baltazar@mendelu.cz (T.B.); oldrich.latal@mendelu.cz (O.L.)

2 Institute of Chemistry and Technology of Environmental Protection, Faculty of Chemistry, Brno University of Technology, Purkynova 118, 61200 Brno, Czech Republic; kucerik@fch.vut.cz

3 Institute for Environmental Studies, Faculty of Science, Charles University in Prague, Benatska 2, 12800 Praha, Czech Republic

4 Institute of Environmental Engineering, Warsaw University of Life Sciences, 159 Nowoursynowska, 02-776 Warsaw, Poland

5 Agricultural Research, Ltd., 66441 Troubsko, Czech Republic

check for updates

Citation: Holatko, J.; Bielska, L.; Hammerschmiedt, T.; Kucerik, J.; Mustafa, A.; Radziemska, M.; Kintl, A.; Baltazar, T.; Latal, O.; Brtnicky, M. Cattle Manure Fermented with Biochar and Humic Substances Improve the Crop Biomass, Microbiological Properties and Nutrient Status of Soil. Agronomy 2022, 12, 368. https://doi.org/ 10.3390/agronomy12020368

Academic Editor: Mariangela Diacono

Received: 30 December 2021

Accepted: 28 January 2022

Published: 31 January 2022

Publisher's Note: MDPI stays neutral with regard to jurisdictional claims in published maps and institutional affiliations.

Copyright: (c) 2022 by the authors. Licensee MDPI, Basel, Switzerland. This article is an open access article distributed under the terms and conditions of the Creative Commons Attribution (CC BY) license (https:// creativecommons.org/licenses/by/ $4.0 /)$.
6 Department of Geology and Soil Science, Faculty of Forestry and Wood Technology, Mendel University in Brno, Zemedelska 3, 61300 Brno, Czech Republic

* Correspondence: adnanmustafa780@gmail.com (A.M.); martin.brtnicky@seznam.cz (M.B.)

\begin{abstract}
Co-composting of raw manure with other organic sources has recently gained the attention of the scientific community. In the present study, raw manure and manures enriched with humic substances (Humac) or biochar were co-composted to improve their physico-chemical properties. We conducted an experiment including variants consisting of soil amended with manure $(\mathrm{M})$, manure + Humac $(\mathrm{M}+\mathrm{H})$, manure + biochar $(\mathrm{M}+\mathrm{B})$, and unamended (control). Soil physico-chemical, biological, and plant properties were assessed altogether. All matured manures differed from each other physico-chemically (nutrient content) and in microbial composition, and hence their effects on the observed parameters. Compared to control, the soil respiration and enzyme activities related to $\mathrm{N}$ and $\mathrm{P}$ mineralization were enhanced due to the amendment of either manure or enriched manures. The $\mathrm{M}+\mathrm{H}$ treatment resulted in higher $\mathrm{pH}$ of the manures as compared to other treatments, whereas the $\mathrm{M}+\mathrm{B}$ and $\mathrm{M}$ treatments revealed the highest $\mathrm{C}_{\text {org }}$ contents of the final product, which was negatively correlated with HA:FA. In the same manner, $\mathrm{M}+\mathrm{H}$ and $\mathrm{M}+\mathrm{B}$ were the most prominent treatments, causing higher variations in basal soil respiration. The same treatments resulted in the highest percent increase values of soil enzymes related to $C, N$, and $P$, which further show the potential of manure modification as a viable option to boost soil fertility and health.
\end{abstract}

Keywords: soil carbon; soil enzymes; soil respiration; manure microflora; plant production

\section{Introduction}

Decreased soil fertility and degradation of croplands are the key challenges faced by farmers in recent eras. Organic matter is a universal indicator of soil quality and is considered an important component of healthy soils [1]. Its loss or decrease can result in reduced soil fertility or complete degradation of agricultural soils [2]. One way to enhance soil fertility is the use of high-quality manure as the primary source of organic matter and nutrients. Manure application to soil has a positive effect on crop yields, soil chemical and physical properties, and soil microbial activities, resulting in the accelerated recycling of nutrients [3-5], with the exception of suboptimal nitrogen: the phosphorus ratio [6]. 
The quality and composition of cattle manure may vary depending upon the production technology, type of bedding [7] and the used litter, and animal feeding management (type of diet) or animal category (cow, horse, pig, etc.). The resulting product is always characterized by a high content of organic matter and nutrients.

Recent studies have focused on the benefits arising from the enrichment or co-application of manure with biochar or humic substances [8,9]. Biochar is a charred organic material used to enhance soil fertility and to sequester carbon [10]. Biochar production from residual crops biomass offers an opportunity for both using the agricultural co-products more efficiently and reducing the number of agricultural wastes (e.g., rice husks, wheat straw) [11] The application of biochar can improve various biological [12] and chemical [10] properties of soils. For example, biochar may stimulate microbial activity in low fertile soils [13] and positively affect the organic matter transformation in soil, resulting in higher available nutrients [14]. Moreover, the addition of biochar reduced nutrient loss during the manure fermentation process [15], as well as improved the chemical parameters and the content of humic substances. The biochar amendment changed the thermodynamics and heat generation during the manure fermentation process [16]. Biochar added to manure increased the manure functional diversity [17], albeit the biochar itself provides numerous benefits to soil, the application of sole biochar did not always result in a positive effect on the soil properties and crop yield. Therefore, its modification by co-composting or mixing it with manure, human feces, food waste, or agricultural residues is recommended [18].

Humic acids (HAs) are ubiquitous organic compounds that can be found in soils, peats, sediments, and low-rank coals. Their positive effect on soil fertility is well known. This impact of HA is ascribed to its ability to solubilize and transport nutrients, bind the contaminants, stimulate plant growth [19], and improve various soil chemical and physical parameters $[20,21]$.

The positive effects of the combined manure-HAs or manure-biochar soil applications have been reported in several studies. Co-applied manure and HA benefit the soil through increasing soil microbial biomass carbon [22], soil aggregation, cation exchange capacity, total carbon, and nitrogen [23]. Biochar addition to manure results in improved humification during the fermentation process [24], and biochar added to the cattle feed provided feces which after fermentation formed biochar enriched- manure having higher availability of $\mathrm{N}$ and $\mathrm{P}$ when amended to soil [25]. Biochar combined with manure also increased plant biomass yield under water-limited conditions [26-28], which suggests the advantage of using combined manure and biochar under currently increasing global water scarcity in agro-ecosystems.

In the present study, we intended to investigate the impact of manure combined with biochar or humic acids on the properties of the produced amendments and evaluate its possible benefits to soil and plants. Manure fermented alone or with biochar or with commercially available humic substances-Humac - was tested for its effect on both the soil physico-chemical and biological properties when applied in the pot experiment with barley (Hordeum vulgare L.). The novelty of our approach lies especially in the use of combined manure-humic substances material for fermentation and as a soil amendment, which, to our knowledge, has not been studied before. We hypothesized that the amendments (manure plus biochar and manure plus humic substances) would: (I) act synergistically and improve both manure and soil properties in comparison to the solely fermented manure; (II) added materials (biochar, Humac) would lead to significant enrichment of manure with nutrients.

\section{Materials and Methods}

\subsection{Fermentation Experiment}

The fermentation experiment was carried out using three variants according to mixed materials: (i) manure only (control), (ii) manure mixed with humic substances, i.e., Humac $(\mathrm{H})$, and (iii) manure mixed with biochar (B). The amounts of materials (in $\mathrm{kg}$ ) used in the 
variant preparation equaled the soil application doses $\left(\mathrm{t} \cdot \mathrm{ha}^{-1}\right)$ for the plant experiment are defined in Table 1.

Table 1. Variants of the fermentation experiment.

\begin{tabular}{|c|c|c|c|c|c|c|}
\hline Variant & $\begin{array}{l}\text { Manure } \\
{\left[t \cdot h a^{-1}\right]}\end{array}$ & $\begin{array}{l}\text { Biochar } \\
{\left[t \cdot h a^{-1}\right]}\end{array}$ & $\begin{array}{l}\text { Humac } \\
{\left[t \cdot h a^{-1}\right]}\end{array}$ & $\begin{array}{c}\text { Manure } \\
{\left[\mathrm{kg} \cdot \text { Barrel }^{-1}\right]}\end{array}$ & $\begin{array}{c}\text { Biochar } \\
{\left[\mathrm{kg} \cdot \text { Barrel }^{-1}\right]}\end{array}$ & $\begin{array}{c}\text { Humac } \\
{\left[\mathrm{kg} \cdot \text { Barrel }^{-1}\right]}\end{array}$ \\
\hline Control & 50 & 0 & 0 & 10 & 0 & 0 \\
\hline Humac $(\mathrm{H})$ & 50 & 0 & 0.5 & 10 & 0 & 0.1 \\
\hline Biochar (B) & 50 & 2 & 0 & 10 & 0.4 & 0 \\
\hline
\end{tabular}

All mixtures were prepared in triplicates. Fresh manure was procured from cattle breed farm and biochar produced from agricultural waste (cellulose fibers and cereal husks) at $600{ }^{\circ} \mathrm{C}$ (Sonnenerde $\mathrm{GmbH}$, Riedlingsdorf, Austria) as obtained from a commercial manufacturer. According to the manufacturer, the properties of the biochar were as follows (content expressed in dry matter): C $86.6 \%, \mathrm{~N} 3.0 \mathrm{~g} \cdot \mathrm{kg}^{-1}, \mathrm{O} 10.0 \mathrm{~g} \cdot \mathrm{kg}^{-1}, \mathrm{H} 14.2 \mathrm{~g} \cdot \mathrm{kg}^{-1}$, Ca $35 \mathrm{~g} \cdot \mathrm{kg}^{-1} ; \mathrm{Ash}_{550{ }^{\circ} \mathrm{C}} 11.7 \%$, salts $0.42 \%, \mathrm{pH}\left(\mathrm{CaCl}_{2}\right) 8.5$, BET $288.5 \mathrm{~m}^{2} \cdot \mathrm{g}^{-1}$. Humac named (AGRO soil fertility stimulator), originally derived from leonardite-oxyhumolite, composed of (dry matter $\geq 85 \%$; free HA $\geq 50 \%$; C 38.4\%, O 18.6\%, N 3.1\%, Na 1.5\%, Ca 1.5\%, Fe 1.6\%, $\mathrm{K} 1.1 \%$, Zn $64 \mathrm{mg} \cdot \mathrm{kg}^{-1}$, B $77 \mathrm{mg} \cdot \mathrm{kg}^{-1}$, Cu $19 \mathrm{mg} \cdot \mathrm{kg}^{-1}$, Se $1.67 \mathrm{mg} \cdot \mathrm{kg}^{-1}$, all in dry matter; pH 6.5 (Envi Produkt Ltd., Prague, Czech Republic).

In amended manure variants, the manure and additives (Humac or biochar) were thoroughly mixed by intensive mixing in the 50 L-barrels. The barrels were tightly covered, and fermentation process was carried out for 58 days at stable temperature $22.2-25.2{ }^{\circ} \mathrm{C}$ and relative humidity $60-78 \%$. The flow of air was not controlled but was limited due to the covering. At the end of the fermentation process, samples were collected from each barrel and analyzed for dry matter (DM), $\mathrm{pH}$ (measured in $\mathrm{CaCl}_{2}$ suspension), organic carbon $\left(\mathrm{C}_{\text {org }}\right)$, total nitrogen $(\mathrm{N})$, ammonium nitrogen $\left(\mathrm{N}-\mathrm{NH}_{4}\right.$, determined according to [29], phosphate $(\mathrm{P})$, potassium $(\mathrm{K})$, calcium $(\mathrm{Ca})$, magnesium $(\mathrm{Mg})$, boron $(\mathrm{B})$, humic:fulvic acid ratio (HA:FA), ammonium-oxidizing bacteria (AOB), denitrifying microorganisms (nirS) (results in Section 3.1).

\subsection{Sampling of Biosolids, Chemical and Microbiological Properties}

Manure was dried to the constant weight at $60{ }^{\circ} \mathrm{C}$ and sieved through a $0.15-\mathrm{mm}$ mesh prior to analyses. DM was estimated gravimetrically. The $\mathrm{pH}$ (in $\mathrm{CaCl}_{2}$ extract from fresh manure) was measured according to ISO 10390: 2005 [30]. $\mathrm{C}_{\text {org }}$ was measured by dry combustion method [31]. Phosphorous (P) was estimated by following the protocol of [32]. Nitrogen (N) composition of biochar was determined using LECO TruSpec analyzer (MI USA). Elemental composition was determined according to standardized method [33]. HA:FA ratio was determined from the contents measured according to [34]. Samples for determination of AOB and nirS by qPCR were freeze-dried and sieved through a $0.15-\mathrm{mm}$ mesh. DNA was extracted from $0.2 \mathrm{~g}$ of freeze-dried sample using the E.Z.N.A. ${ }^{\circledR}$ Soil DNA Kit (Omega Bio-tek, Norcross, GA, USA). The SYBR-Green platform was used on a CFX96 Real-Time PCR detection system (Bio-Rad Laboratories, Hercules, CA, USA). AOB were quantified according to the protocol of Rotthauwe et al. [35], nirS (nitrate reductase gene copies) were quantified according to the method developed by Kandeler et al. [36].

\subsection{Pot Experiment and Design}

The pot experiment with barley (Hordeum vulgare L.) as a test crop was performed. The 5-L pots-top diameter $22 \mathrm{~cm}$, base diameter $17 \mathrm{~cm}$, height $18 \mathrm{~cm}$-were used. First, the pots were filled up with $5 \mathrm{~kg}$ of a soil-sand mixture (1:1), where fine quartz sand $(0.1-1.0 \mathrm{~mm})$ was mixed with sieved $(2.0 \mathrm{~mm})$ topsoil collected from the rural area near the town Troubsko (Czech Republic $-49^{\circ} 10^{\prime} 28^{\prime \prime} \mathrm{N} 16^{\circ} 29^{\prime} 32^{\prime \prime} \mathrm{E}$ ). The soil was silty clay loam (according to USDA Textural Soil Classification), Haplic luvisol (according to the WRB Soil 
Classification-FAO [37], its properties are shown in (Table 2). Selected pots were further amended with fermented manure or enriched manures with Humac or biochar.

Table 2. Properties of soil used in the pot experiment.

\begin{tabular}{|c|c|c|c|c|c|c|}
\hline $\begin{array}{c}\text { pH } \\
7.29\end{array}$ & $\begin{array}{c}\text { TN [\%] } \\
0.16\end{array}$ & $\begin{array}{c}\text { TC }[\%] \\
1.40\end{array}$ & $\begin{array}{l}\text { C:N } \\
8.77\end{array}$ & $\begin{array}{c}\mathbf{N}_{\min }\left[\mathbf{m g} \cdot \mathbf{k g}^{-\mathbf{1}}\right] \\
62.84\end{array}$ & $\begin{array}{c}\mathbf{N}-\mathrm{NO}_{3}\left[\mathbf{m g} \cdot \mathbf{k g}^{-\mathbf{1}}\right] \\
56.80\end{array}$ & $\begin{array}{c}\mathrm{N}-\mathrm{NH}_{\mathbf{4}}\left[\mathrm{mg} \cdot \mathrm{kg}^{-\mathbf{1}}\right] \\
6.04\end{array}$ \\
\hline & $\mathbf{H}[\%]$ & S [\%] & $\mathrm{K}\left[\mathrm{mg} \cdot \mathrm{kg}^{-1}\right]$ & $\mathrm{Ca}\left[\mathrm{mg} \cdot \mathrm{kg}^{-1}\right]$ & $\mathrm{Mg}\left[\mathrm{mg} \cdot \mathrm{kg}^{-1}\right]$ & $P\left[\mathrm{mg} \cdot \mathrm{kg}^{-1}\right]$ \\
\hline & 0.58 & 0.01 & 231 & 3259 & 236 & 97 \\
\hline
\end{tabular}

$\mathrm{TN}=$ soil total nitrogen, $\mathrm{TC}=$ soil total carbon, $\mathrm{C}: \mathrm{N}=$ soil total carbon/total nitrogen ratio, $\mathrm{N}_{\min }=$ mineral nitrogen $\mathrm{N}-\mathrm{NO}_{3}$ nitrate nitrogen, $\mathrm{N}-\mathrm{NH}_{4}=$ ammonium nitrogen, $\mathrm{H}=$ soil hydrogen, $\mathrm{S}=$ soil sulphur, $\mathrm{K}=$ soil potassium $\mathrm{Ca}=$ soil calcium, $\mathrm{Mg}=$ soil magnesium, $\mathrm{P}=$ soil phsphorus.

The following treatments were used (i) the unamended soil (soil control), and three variants of soil amended with (ii) fermented manure (control, M), (iii) manure enriched with Humac $(\mathrm{M}+\mathrm{H})$, and (iv) manure enriched with biochar $(\mathrm{M}+\mathrm{B})$. The amendment dose was $165 \mathrm{~g} \cdot \operatorname{pot}^{-1}$ (with equaled 50-tonne biosolid $\cdot \mathrm{ha}^{-1}$ ). Each variant (except for the soil control) was amended with a mixed manure variant () and prepared in four replicates. Each pot was watered with distilled water to $65 \%$ WHC (which was maintained throughout the experiment), and 16 barley seeds were sown in each pot. After 2 weeks, the number of plants in the pots was reduced to 13. The experiment was carried out for 12 weeks in a growth chamber (CLF Plant Climatics $\mathrm{GmbH}$, Germany) under controlled conditions (day / night): temperature $\left(20 / 12{ }^{\circ} \mathrm{C}\right)$, relative air humidity $(45 / 70 \%)$, photoperiod $(12 / 12 \mathrm{~h})$, light intensity of $370 \mu \mathrm{moL} \cdot \mathrm{m}^{-2} \cdot \mathrm{s}^{-1}$.

\subsection{Soil Sampling, Physico-Chemical, and Enzymatic Analyses}

At the end of the experiment, the above-ground plant biomass was harvested at the ground level, dried at $60^{\circ} \mathrm{C}$ to constant weight, and reported as dry AGB. The substrate from each pot was homogenized by sieving it through $2 \mathrm{~mm}$ mesh under sterile conditions and sampled for further analysis. Air dried soil samples were analyzed for physicochemical properties, i.e., $\mathrm{pH}$ [30], total soil C (TC) [31], total soil N (TN) [38]. Freeze-dried samples were used for the analyses of enzymatic activities: $\beta$-glucosidase (GLU), arylsulfatase (ARS), phosphatase (Phos), urease (Ure), $N$-acetyl- $\beta$-D-glucosaminidase (NAG) [39]. The samples stored at $4{ }^{\circ} \mathrm{C}$ were used for determination of dehydrogenase activity (DHA) following Casida et al. (1964) [40], soil basal respiration (BR) and substrate-induced respiration (SIR)—D-glucose (Glc-SIR), citric acid (Cit-SIR), D-trehalose (Tre-SIR), N-acetyl$\beta$-D-glucosamine (NAG-SIR), L-alanine (Ala-SIR), L-lysine (Lys-SIR), or L-arginine (ArgSIR) [41].

\subsection{Statistical Analyses}

Data obtained from the physico-chemical and biological measurements were statistically analyzed using the multivariate analysis of variance (MANOVA), principal component analysis (PCA), one-way analysis of variance (ANOVA), Tukey HSD post hoc test (at significance level $p=0.05$ ), and Pearson correlation analysis (Program $R$, version 3.6.1).

The results of Pearson's correlation analysis were interpreted as follows: $0.5<\mathrm{r}<0.7$ (moderate correlation) and $0.7<\mathrm{r}<0.9$ (high correlation) [42].

\section{Results}

\subsection{Effect of Amendments on Manure Maturation}

The results revealed that all three variants differed significantly from each other in terms of physical, chemical, and biological characteristics (Table 3). 
Table 3. Properties of the maturated manure variants (mean \pm standard deviation, $n=3$, * statistically significant difference at $p \leq 0.05$ ).

\begin{tabular}{|c|c|c|c|}
\hline & $\mathbf{M}$ & $\mathbf{M}+\mathbf{H}$ & $\mathbf{M}+\mathbf{B}$ \\
\hline & Mean \pm SD * & Mean \pm SD * & Mean \pm SD * \\
\hline $\mathrm{DM}[\%]$ & $30.01 \pm 0.02 c$ & $31.22 \pm 0.02 b$ & $31.48 \pm 0.02 \mathrm{a}$ \\
\hline $\mathrm{pH}[-]$ & $9.04 \pm 0.01 b$ & $9.25 \pm 0.01 \mathrm{a}$ & $9.05 \pm 0.01 b$ \\
\hline $\mathrm{C}_{\text {org }}[\%]$ & $13.50 \pm 0.28 \mathrm{a}$ & $12.45 \pm 0.36 b$ & $13.01 \pm 0.14 \mathrm{a}$ \\
\hline $\mathrm{N}[\%]$ & $2.48 \pm 0.05 \mathrm{a}$ & $2.49 \pm 0.05 \mathrm{a}$ & $2.54 \pm 0.03 \mathrm{a}$ \\
\hline $\mathrm{N}-\mathrm{NH}_{4}\left[\mathrm{mg} \cdot \mathrm{kg}^{-1}\right]$ & $2.06 \pm 0.02 \mathrm{a}$ & $1.56 \pm 0.04 b$ & $1.44 \pm 0.08 c$ \\
\hline $\mathrm{P}[\%]$ & $4.22 \pm 0.36 \mathrm{a}$ & $3.58 \pm 0.58 \mathrm{a}$ & $3.45 \pm 0.64 \mathrm{a}$ \\
\hline $\mathrm{K}\left[\mathrm{g} \cdot \mathrm{kg}^{-1}\right]$ & $84.36 \pm 5.21 \mathrm{a}$ & $87.57 \pm 3.87 \mathrm{a}$ & $67.03 \pm 2.62 b$ \\
\hline $\operatorname{Mg}\left[\mathrm{g} \cdot \mathrm{kg}^{-1}\right]$ & $9.61 \pm 0.50 \mathrm{a}$ & $9.30 \pm 0.15 \mathrm{a}$ & $7.34 \pm 0.18 b$ \\
\hline $\mathrm{Ca}\left[\mathrm{g} \cdot \mathrm{kg}^{-1}\right]$ & $20.93 \pm 0.88 b$ & $22.68 \pm 0.88 b$ & $32.95 \pm 1.96 \mathrm{a}$ \\
\hline $\mathrm{B}\left[\mathrm{mg} \cdot \mathrm{kg}^{-1}\right]$ & $47.20 \pm 1.11 \mathrm{a}$ & $43.78 \pm 2.49 \mathrm{a}$ & $54.53 \pm 9.35 \mathrm{a}$ \\
\hline HA:FA [-] & $0.79 \pm 0.01 \mathrm{~b}$ & $1.20 \pm 0.07 \mathrm{a}$ & $0.69 \pm 0.03 c$ \\
\hline AOB $\left[\right.$ copies $\left.\cdot g^{-1}\right]$ & $2.11 \cdot 10^{8} \pm 2.63 \cdot 10^{7} \mathrm{a}$ & $1.01 \cdot 10^{8} \pm 1.38 \cdot 10^{7} \mathrm{~b}$ & $2.09 \cdot 10^{8} \pm 3.63 \cdot 10^{6} \mathrm{a}$ \\
\hline $\operatorname{nirS}\left[\right.$ copies $\left.^{\prime} \mathrm{g}^{-1}\right]$ & $1.07 \cdot 10^{9} \pm 1.59 \cdot 10^{8} \mathrm{c}$ & $1.87 \cdot 10^{9} \pm 2.38 \cdot 10^{8} \mathrm{a}$ & $1.40 \cdot 10^{9} \pm 1.69 \cdot 10^{8} \mathrm{~b}$ \\
\hline
\end{tabular}

M; manure, $\mathrm{M}+\mathrm{H}$; manure + Humac, $\mathrm{M}+\mathrm{B}$; manure + biochar. SD = standard deviation. Letters indicate differences between the values at the statistical level of significance $p \leq 0.05$.

The differences between the $\mathrm{M}+\mathrm{H}$ variant and the other two variants (as depicted in Figure 3A) can be seen, e.g., the $\mathrm{pH}$ was higher for the $\mathrm{M}+\mathrm{H}$ variant compared to the $\mathrm{M}+\mathrm{B}$ variant and the $\mathrm{M}$ variant (Table 3 ). The $\mathrm{pH}$ correlated significantly positively with nirS $(\mathrm{r}=0.82)$ and negatively with $\mathrm{C}_{\text {org }}$ and $\mathrm{AOB}(\mathrm{r}=-0.82$ and -0.81 , respectively (Figure 2A). DM also significantly differed between the variants and patterned as follows: $\mathrm{M}<\mathrm{M}+\mathrm{H}<\mathrm{M}+\mathrm{B}$ (Table 3$)$. The $\mathrm{C}_{\text {org }}$ was significantly lower in the $\mathrm{M}+\mathrm{H}$ in comparison to $\mathrm{M}$ and $\mathrm{M}+\mathrm{B}$ (Table 3$)$. $\mathrm{C}_{\text {org }}$ significantly negatively correlated with HA:FA $(\mathrm{r}=-0.7)$ and nirS $(\mathrm{r}=-0.75)$ (Figure $2 \mathrm{~A})$. The total $\mathrm{N}$ was similar across the variants.

Similarly to $\mathrm{N}$ contents, the content of available $\mathrm{P}$ was comparable among the variants where the exact measured values decreased in the following order: $\mathrm{M}>\mathrm{M}+\mathrm{H}>\mathrm{M}+\mathrm{B}$ (Table 3). $\mathrm{P}$ content was moderately positively correlated with $\mathrm{N}-\mathrm{NH}_{4}(\mathrm{r}=0.54)$. The $\mathrm{N}-\mathrm{NH}_{4}$ content significantly decreased in both $\mathrm{M}+\mathrm{H}$ and $\mathrm{M}+\mathrm{B}$ variants as compared to the $M$ variant. Both the $K$ and $M g$ contents in $M+B$ were significantly lower as compared to $\mathrm{M}$ and $\mathrm{M}+\mathrm{H}$. The PCA biplot and Pearson's correlation analyses revealed that $\mathrm{K}$ and $\mathrm{Mg}$ (positively intercorrelated) significantly negatively correlated with calcium (Ca) and boron (B) (positively intercorrelated) (Figures 1 and 2). Due to the higher Ca content in biochar, the resulting content of $\mathrm{Ca}$ in $\mathrm{M}+\mathrm{B}$ was significantly increased as compared to the two other variants. The Ca content correlated moderately positively with total $\mathrm{N}(\mathrm{r}=0.69)$ and negatively with $\mathrm{N}-\mathrm{NH}_{4}(\mathrm{r}=-0.71)$ (Figure 2A). In our study, boron contents were similar across the variants. The HA:FA ratio was not affected by biochar addition while significantly increased in the $\mathrm{M}+\mathrm{H}$ variant. The HA:FA correlated moderately positively with nirS $(r=0.73)$ and $K(r=0.66)$, and negatively with $C_{o r g}(r=-0.7)$ and $A O B(r=-0.87)$ (Figure 2A).

The AOB was significantly lower in $\mathrm{M}+\mathrm{H}$ as compared to the other two variants, and the PCA biplot and Pearson's correlation found an antagonism and negative correlation of AOB with nirS $(\mathrm{r}=-0.74)$ (Figures $2 \mathrm{~A}$ and $3 \mathrm{~A})$. The nirS values significantly differed among the treatments, where it was the highest for $\mathrm{M}+\mathrm{H}$ and the lowest for the $\mathrm{M}$ variant. 


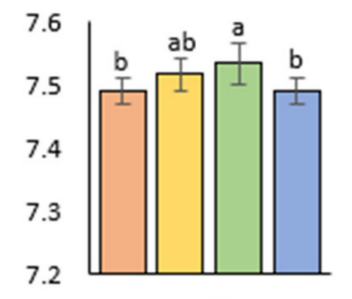

$\mathrm{pH}$

A

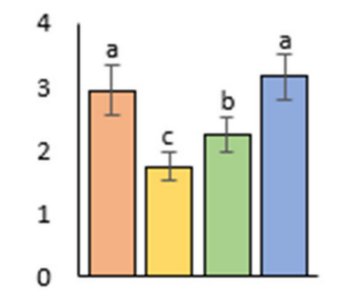

$$
\text { E }
$$

Cit-SIR
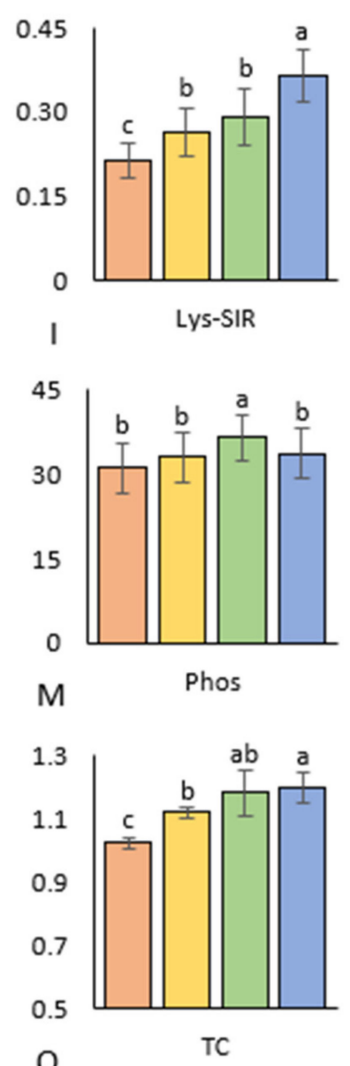

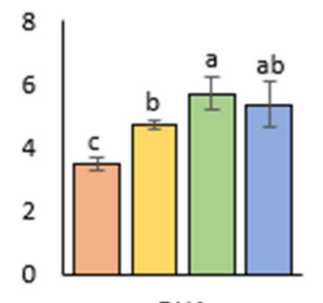

B

DHA

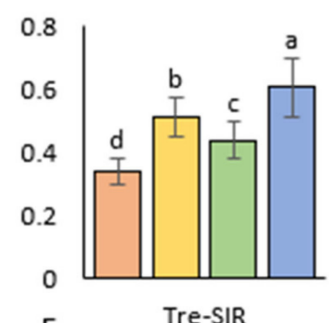

F Tre-SIR
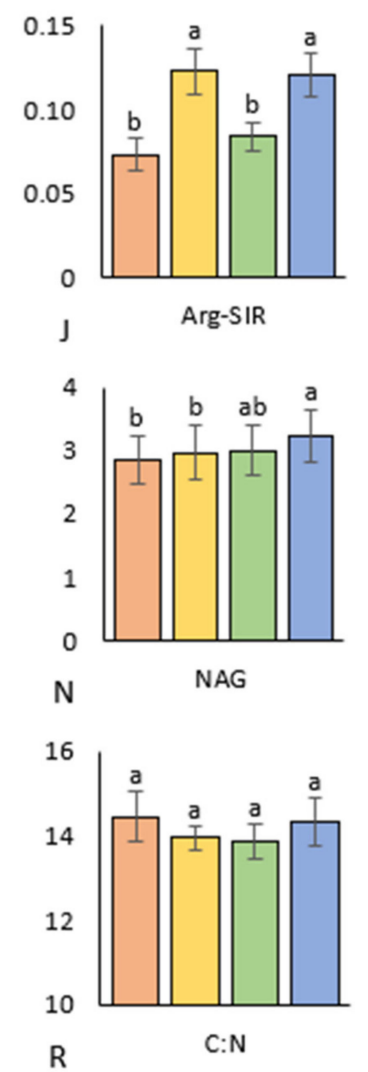

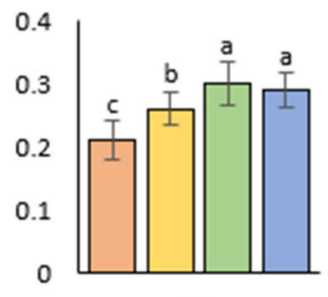

BR

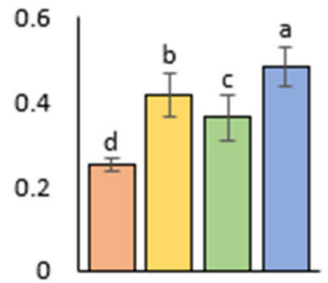

NAG-SIR
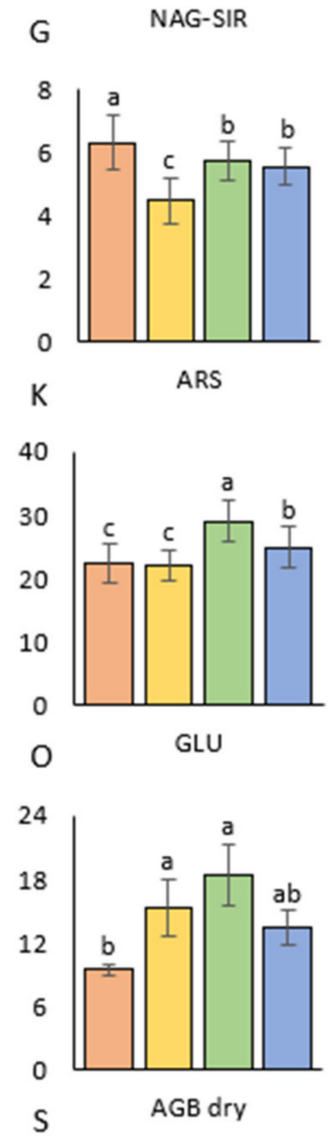

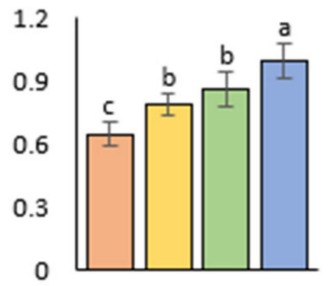

D GIc-SIR

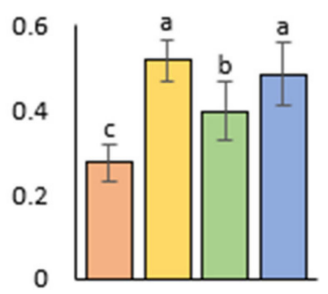

H Ala-SIR
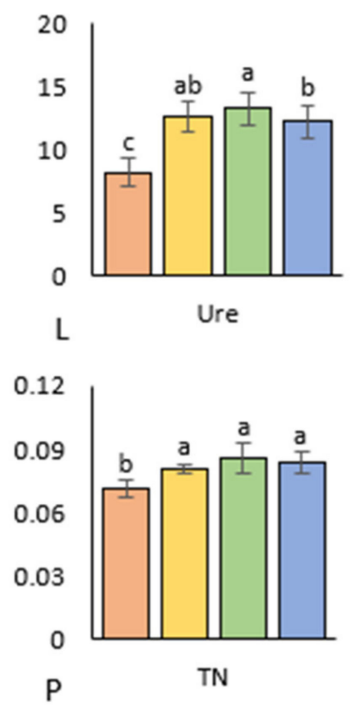

$\square$ Control

$\square \mathrm{M}$

$\mathrm{aM}+\mathrm{H}$

$\square \mathrm{M}+\mathrm{B}$

Figure 1. Results of the pot experiment with four tested variants, i.e., soil (control), soil amended with manure $(M)$, soil amended with manure and Humac $(M+H)$, and soil amended with manure and biochar $(\mathrm{M}+\mathrm{B})$. The measured parameters were as follows: $(\mathrm{A})$ soil reaction $=\mathrm{pH}$ $[-]$, (B) dehydrogenase activity $\left[\mu \mathrm{g}\right.$ TPF $\left.\cdot \mathrm{g}^{-1} \cdot \mathrm{h}^{-1}\right]$, (C) basal respiration $\left[\mu \mathrm{g} \mathrm{CO} \cdot \mathrm{g}^{-1} \cdot \mathrm{h}^{-1}\right]$, (D) Dglucose SIR $\left[\mu \mathrm{g} \mathrm{CO} \mathrm{CO}_{2} \cdot \mathrm{g}^{-1} \cdot \mathrm{h}^{-1}\right]$, (E) citric acid SIR $\left[\mu \mathrm{g} \mathrm{CO}_{2} \cdot \mathrm{g}^{-1} \cdot \mathrm{h}^{-1}\right]$, (F) D-trehalose SIR, (G) N-acetyl$\beta$-D-glucosamine SIR $\left[\mu \mathrm{g} \mathrm{CO} 2 \cdot \mathrm{g}^{-1} \cdot \mathrm{h}^{-1}\right],(\mathbf{H})$ L-alanine SIR $\left[\mu \mathrm{g} \mathrm{CO}_{2} \cdot \mathrm{g}^{-1} \cdot \mathrm{h}^{-1}\right]$, (I) L-lysine SIR $\left[\mu \mathrm{g} \mathrm{CO} \mathrm{CO}_{2} \cdot \mathrm{g}^{-1} \cdot \mathrm{h}^{-1}\right],(\mathrm{J})$ L-arginine SIR $\left[\mu \mathrm{g} \mathrm{CO} 2 \cdot \mathrm{g}^{-1} \cdot \mathrm{h}^{-1}\right],(\mathbf{K})$ arylsulfatase $\left[\mathrm{nmol} \cdot \mathrm{g}^{-1} \cdot \mathrm{min}^{-1}\right],(\mathbf{L})$ urease $\left[\mathrm{nmol} \cdot \mathrm{g}^{-1} \cdot \mathrm{min}^{-1}\right],(\mathbf{M})$ phosphatase $\left[\mathrm{nmol} \cdot \mathrm{g}^{-1} \cdot \mathrm{min}^{-1}\right],(\mathbf{N}) \mathrm{N}$-acetyl- $\beta$-D-glucosaminidase $\left[\mathrm{nmol} \cdot \mathrm{g}^{-1} \cdot \mathrm{min}^{-1}\right],(\mathbf{O}) \beta$-glucosidase $\left[\mathrm{nmol} \cdot \mathrm{g}^{-1} \cdot \mathrm{min}^{-1}\right],(\mathbf{P})$ total soil nitrogen $[\%],(\mathbf{Q})$ total soil carbon [\%], (R) C:N ratio [-], (S) dry plant aboveground biomass [g]. Different letters indicate differences between the values at the statistical level of significance $p \leq 0.05$. 


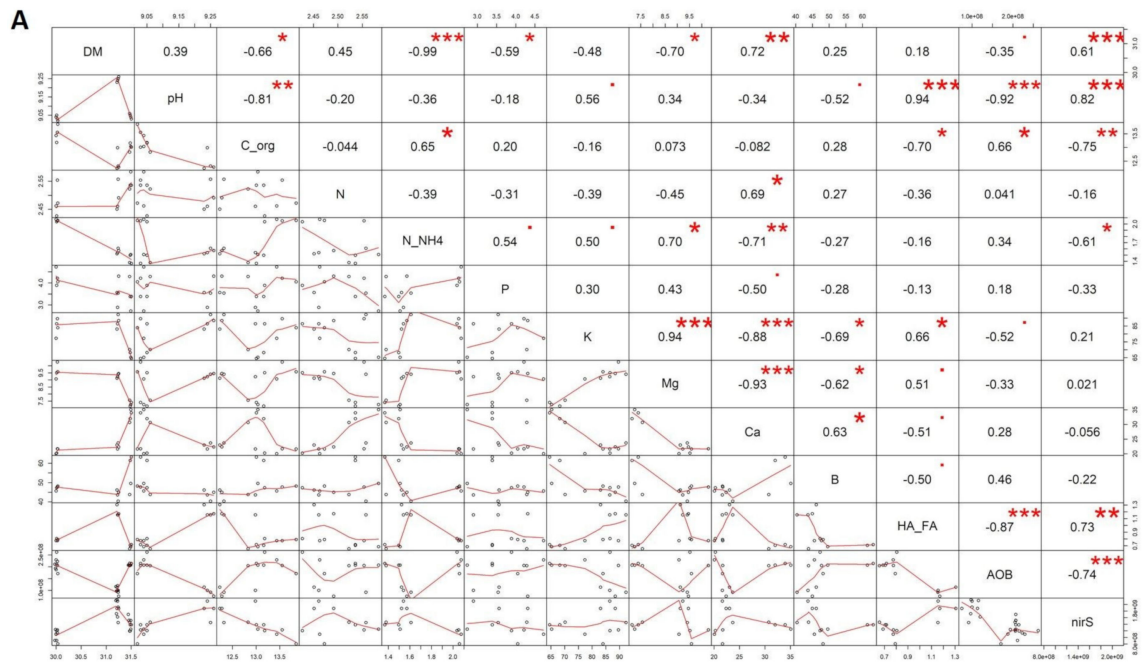

B

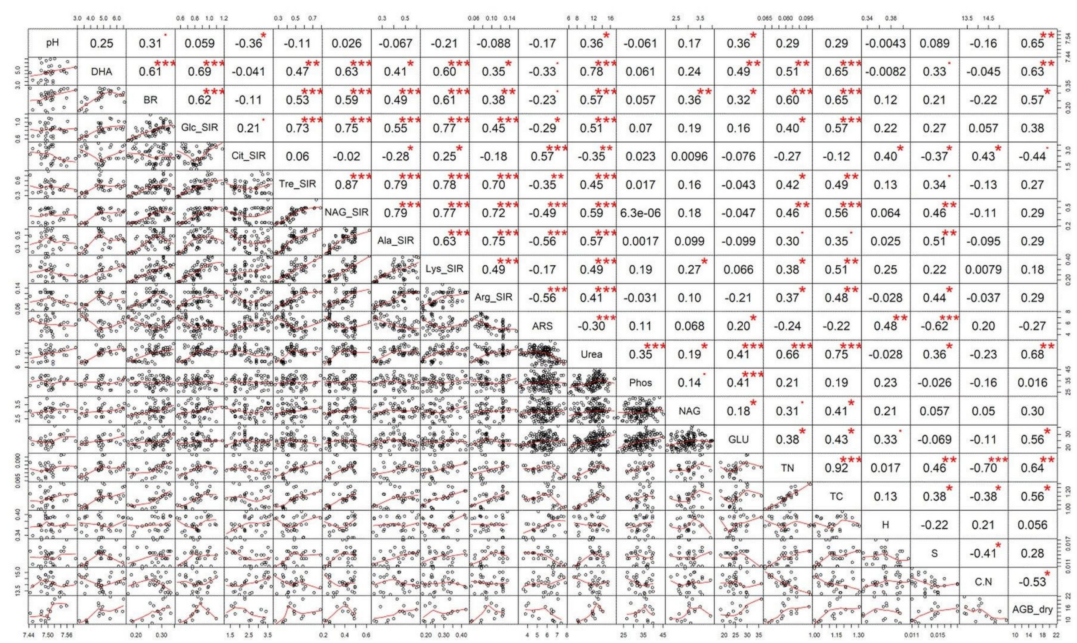

Figure 2. The Pearson's correlation matrix of the maturated manure properties (A), soil, and plant properties (B). Explanation: · Significant at 0.10 level; ${ }^{*}$ Significant at 0.05 level; ${ }^{* *}$ Significant at 0.01 level; ${ }^{* * *}$ Significant at 0.001 level.
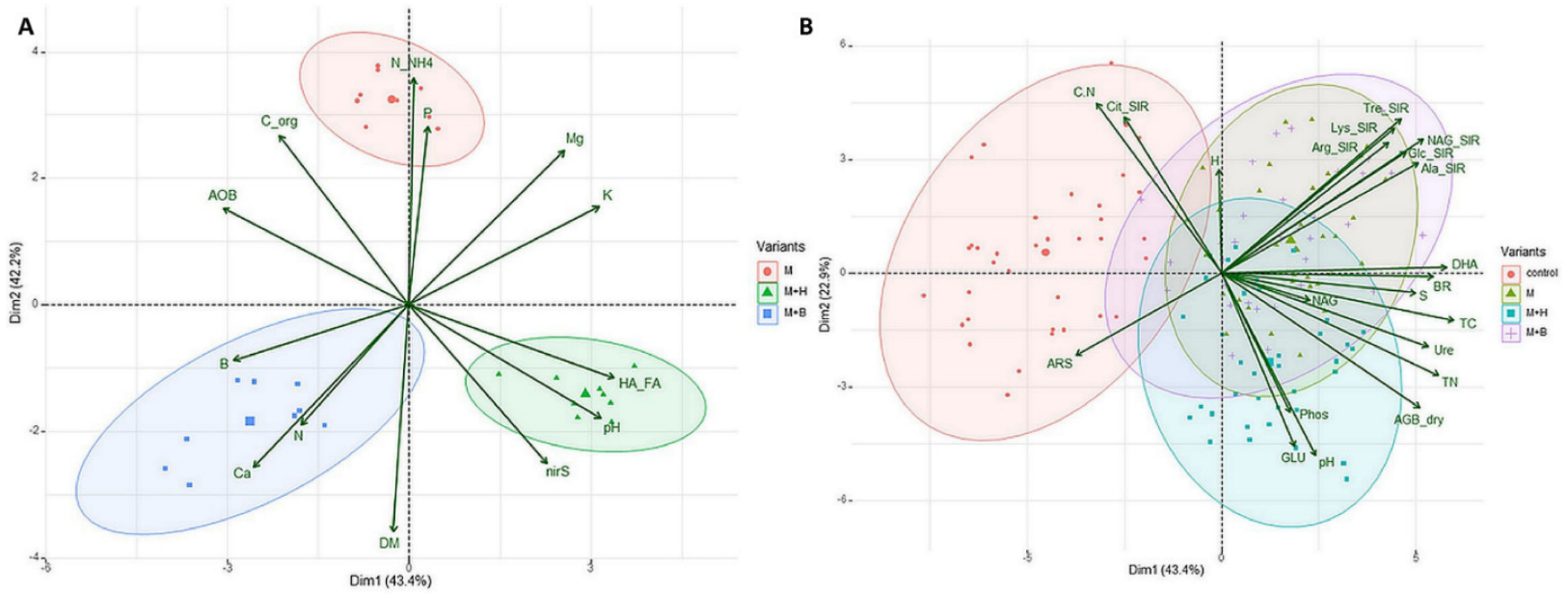

Figure 3. The PCA biplot of the maturated manure properties (A), soil and plant properties (B). (A) $\mathrm{M}=$ fermented manure, $\mathrm{M}+\mathrm{H}=$ manure + Humac, $\mathrm{M}+\mathrm{B}=$ manure + biochar; (B) control = control soil, $\mathrm{M}=$ soil amended with fermented manure; $\mathrm{M}+\mathrm{H}=$ soil amended with manure + Humac, $\mathrm{M}+\mathrm{B}=$ soil amended with manure + biochar. 


\subsection{Effect of Manure and Amendments on Soil Respiration}

The results revealed a significant $(p \leq 0.05)$ increase in basal respiration (BR) in manure amended variants in comparison to control (Figure $1 \mathrm{C}$ ). The combined addition of $\mathrm{M}+\mathrm{H}$ and $\mathrm{M}+\mathrm{B}$ had the most profound effect on the BR of soil. This positive role of the carbon-rich amendments on soil microbial activity was further supported by the observed moderate positive correlation between BR and the TC $(r=0.67)$ (Figure $2 \mathrm{~B})$. The moderate positive correlation between BR and sugars-induced SIR (Glc-SIR- $r=0.54$, Tre-SIR-r = 0.6, NAG-SIR $-r=0.62$ ) and amino acid-induced SIR (Lys-SIR $-r=0.6$, ArgSIR $-r=0.55)$ further corroborates the community-broad positive effect on microbial respiration arising from single $(M)$ or combined applications $(M+H$ or $M+B)$ when compared to control (Figure 2B). However, there were differences between the results of the various SIR assays (i.e., Glc-SIR versus Ala-SIR and Arg-SIR) for the $M, M+H$, and $M+B$ variants, which implies functionally diverse microbiomes in these treatments. The $M+B$ variant showed the highest values in several SIR assays, including Glc-SIR, Tre-SIR, NAG-SIR, and Lys-SIR. (Figure 1D-J).

\subsection{Effect of Manure and Amendments on Soil Nutrient Cycling and or Enzymatic Activities}

Transformation of nutrients in the test soil was affected by the activities of the microbial biomass in the respective experimental variants, which could be documented by, e.g., the agonistic relationship and the moderate positive correlation between DHA and TC $(r=0.48)$ and between DHA and the TN content $(r=0.47)$ (Figure $2 B)$. Further, a positive correlation between DHA and GLU $(r=0.45)$ and between DHA and Ure $(r=0.60)$ was observed (Figure 2B). DHA was found to be significantly increased due to amending the soil with manure (by 35, 63, and 53\% on average for $M, M+H$, and $M+B$ variants, respectively). The manure amendment in soil-stimulated mineralization of soil $\mathrm{C}_{\text {org }}$ is evidenced by the significantly higher DHA in all manure-treated soils as compared to control.

The variants amended with enriched manure $(\mathrm{M}+\mathrm{H}$ and $\mathrm{M}+\mathrm{B})$ showed significantly higher GLU values by $31 \%$ and $12 \%$, respectively, on average compared to control soil. The highest and significantly different (as compared to the control and $\mathrm{M}$ variant) value of GLU was measured in the $\mathrm{M}+\mathrm{H}$ soil (Figure 1O). NAG value significantly higher than in control (and $M$ variant) was reported for the $M+B$ treatment by $13 \%$, compared to control-(Figure 1N). The PCA biplot showed a clear convergence of GLU with Phos as well as NAG with Ure (Figure 3B).

The activity of Ure was higher in the manure-based variants by 61 and $48 \%$ for $\mathrm{M}+\mathrm{H}$ and $\mathrm{M}+\mathrm{B}$, respectively, when compared to the control (Figure 1L). Apart from moderate positive correlation with DHA $(r=0.60)$, the Ure activity correlated also with NAG-SIR $(\mathrm{r}=0.46)$, Ala-SIR $(\mathrm{r}=0.50)$, and dry AGB $(\mathrm{r}=0.53)$ (Figures $2 \mathrm{~B}$ and $3 \mathrm{~B})$.

Relative to control, the activity of Phos significantly increased only in the $\mathrm{M}+\mathrm{H}$ variant (Figure $1 \mathrm{M})$ and showed a significant correlation with Ure $(\mathrm{r}=0.35)$ and with GLU $(\mathrm{r}=0.41)$ (Figure 2B). On the contrary, ARS activity significantly decreased following the addition of all manures to the soil, especially of $\mathrm{M}$, by $29 \%$ on average (Figure $1 \mathrm{~K}$ ). ARS activities in the $\mathrm{M}+\mathrm{H}$ and $\mathrm{M}+\mathrm{B}$ variants were comparable. The PCA biplot revealed antagonism between ARS activities and the results of the SIR assays (except Cit-SIR) (Figure 3B).

\subsection{Effect of Manure and Amendments on Soil Physico-Chemical Properties and Plant Biomass}

The $\mathrm{pH}$ values significantly differed between the tested variants. The control treatment and $\mathrm{M}+\mathrm{B}$ showed significantly lower values than the soil in $\mathrm{M}+\mathrm{H}$ treatment (Figure 1A). The $\mathrm{pH}$ values moderately positively correlated with dry AGB $(\mathrm{r}=0.55)$, that increased (compared to the control) in soil when amended with manure $(+62 \%$, in average), $\mathrm{M}+\mathrm{B}$ $(+43 \%)$ and especially with $\mathrm{M}+\mathrm{H}(+95 \%$, Figure $1 \mathrm{~S})$. Dry AGB was further positively correlated with the soil TC and TN content ( $\mathrm{r}=0.52$ and 0.30 , respectively) in the test variants. The TC content (Figure 1P) was significantly higher compared to control (by $9 \%$, $15 \%$, and $17 \%$ ) in all manure-based variants $(\mathrm{M}, \mathrm{M}+\mathrm{H}$, and $\mathrm{M}+\mathrm{B}$, respectively). The 
PCA biplot indicated TC agonisms with BR and enzyme activities (i.e., DHA, NAG, Ure) (Figure 3B).

The soil TN content (Figure 1P) was significantly higher (by 13\%, 21\%, 18\%) in all manure-based variants ( $M, M+H, M+B$, respectively) as compared to control). Significantly positively correlated with TC $(\mathrm{r}=0.79)$ and moderately negatively correlated with $\mathrm{C}: \mathrm{N}(\mathrm{r}=-0.61)$ (Figure 1R,S and Figure 2B). No significant difference was found in C:N among the variants; however, high average values of $C: N$ in the control and $M+B$ variants were in contrast to the low average values of AGB dry (Figure 1R,S).

\section{Discussion}

\subsection{Effect of Amendments on Manure Maturation}

Manure maturation is connected with the activity of various groups of microorganisms, especially bacteria, fungi, and actinomycetes. The intensity of these processes is determined by the access of air, ambient humidity, and temperature, which were kept the same in all cases in the present study. With access to air, the decomposition of organic substances proceeds much faster than in anaerobic conditions, and there are large losses of organic matter and especially nitrogen, which is rapidly lost as ammonia. With limited air access (mild anaerobiosis conducted in this work), organic matter is only partially degraded from manure, and more methane would have formed, which prevents the decomposition of organic matter into carbon dioxide, water, and ammonia [43].

As expected, the DM content of the enriched manure was influenced by Humac and Biochar enrichment, which was given by the vast difference between the DM of manure $(\sim 30.0 \%)$, Humac $(\geq 85 \%$, added in $1 \% w / w)$, and biochar $(\geq 65 \%$, added in $4 \%$ $w / w)$. Despite our initial expectations, the alkaline nature of biochar $(\mathrm{pH}=9.6)$ did not significantly impact the resulting $\mathrm{pH}$ of the $\mathrm{M}+\mathrm{B}$ mixture compared to the $\mathrm{M}$ variant, which can be attributed to the type and amount of used biochar. On the contrary, Humac addition in $\mathrm{M}+\mathrm{H}$ variant caused a significant increase in $\mathrm{pH}$ when compared to the unamended manure (M). The negative correlation of $\mathrm{pH}$ with $\mathrm{C}_{\text {org }}$ and $\mathrm{AOB}$ implied that microbial mineralization processes took place and affected the $\mathrm{pH}$ of the mixtures. We assume that the available $\mathrm{C}_{\text {org }}$ and $\mathrm{N}-\mathrm{NH}_{4}$ in the $\mathrm{M}+\mathrm{B}$ variant were aerobically (or partially anaerobically) oxidized, which putatively lead to Ca precipitation, similarly as it occurred in broiler litter due to urea hydrolysis as reported previously by Burt et al. [44]. Concurrently, increased ammonia oxidation might have decreased the $\mathrm{pH}$ and caused decreased $\mathrm{N}_{-} \mathrm{NH}_{4}$ content.

With biochar ( $86.6 \%$ C, dry weight) and Humac (38.4\% C d. w.), a significant portion of fresh $\mathrm{C}$ was introduced to the manure, yet the $\mathrm{C}_{\text {org }}$ content in the matured $\mathrm{M}+\mathrm{H}$ mixture was lower when compared to $M$ and the $M+B$ variants. We assume that $C_{\text {org }}{ }^{-}$ rich amendments $(\mathrm{M}+\mathrm{H}, \mathrm{M}+\mathrm{B})$ facilitated decomposition and humification as reported previously [45]. A high amount of HAs was added to the $\mathrm{M}+\mathrm{H}$ mixture as well. However, we presumed that humic acid-derived carbon underwent intensified mineralization due to the higher solubility of humic acid under increased $\mathrm{pH}$ as referred by [46] and concurrently increased vulnerability to auto-oxidation [47]. Another study by [48] reported that increased carbon oxidation (prevailing in $\mathrm{M}+\mathrm{B}$ and $\mathrm{M}+\mathrm{H}$, in contrast to $\mathrm{M}$ ) was coupled with higher denitrification because this may be caused by depletion in oxygen availability. Moreover, Paul and Beauchamp, and Dlamini et al. [49,50], also reported that water-soluble C, VFA, or particular carbon sources in manure might promote denitrification. The findings by Sarkhot et al. [51] suggested that biochar can stabilize the various forms of $\mathrm{N}$ in manure via various adsorption mechanisms. Agyarko-Mintah et al. [52], in another study, reported increased $\mathrm{N}$ retention during manure composting, while $\mathrm{N}-\mathrm{NH}_{4}$ was decreased during the maturation phase. Yet, our data implied that the addition of biochar to manure did not affect the total $\mathrm{N}$ contents that were found to be similar across the various treatments at the end of the maturation experiment. Similarly, we did not observe significant changes in the P contents as a result of the addition of either Humac or biochar to manure before its maturation, and therefore we cannot corroborate the results of previous studies [53,54] suggesting that organic matter contributes to P stabilization. 
The contents of $\mathrm{K}$ and $\mathrm{Mg}$ in the $\mathrm{M}+\mathrm{B}$ variant were lower, whereas the content of $\mathrm{Ca}$ was higher when compared to the other variants (Table 3). These trends were fully in line with the composition of biochar that was less rich in $\mathrm{K}$ and $\mathrm{Mg}$ while richer in the Ca when compared to manure (Table 3).

The addition of Humac, as a material rich in humic acids $(\geq 50 \%)$, resulted in a higher HA:FA ratio when compared to other variants. Additionally, we assume that fulvic acid formation was further promoted in the $\mathrm{M}+\mathrm{H}$ variant via increased degradation (mineralization) of the organic matter (as evidenced by the lowest $\mathrm{C}_{\text {org }}$ content). These findings were further supported by the observed antagonism of AOB and HA:FA as shown by PCA biplot (Figure 3A), which further corroborates the role of fulvic acids in anaerobic ammonium oxidation and carbon mineralization. Similarly, it was evidenced by Liu et al. [55], who found out that the addition of FA into denitrifying bacterial culture resulted in FA-accelerated metabolism of carbon source.

The highest $\mathrm{pH}$ and HA:FA ratio, promoting denitrification, and lower available $\mathrm{N}$ $\mathrm{NH}_{4}$ (compared to the fermented manure) in the $\mathrm{M}+\mathrm{H}$ variant (Table 3 ) were critical parameters for the lowest abundance of AOB in this treatment. On the other hand, the same critical traits ( $\mathrm{pH}, \mathrm{HA}: \mathrm{FA})$, which limited the numbers of AOB, anticipated the increased abundance of denitrifying microorganisms (determined as nirS) in the $\mathrm{M}+\mathrm{H}$ as compared to the other two tested variants.

\subsection{Effect of Manure and Amendments on Soil Respiration}

In previous works, it has been reported that both the single application of manure and combined with biochar can stimulate soil respiration [56]. The addition of compost or manure enriched with humic acids also increased soil microbial biomass [23,45]. In contrast, the single application of Humac to soil resulted in decreased BR [57]. In our study, the application of all manure types significantly increased BR as compared to the control soil.

Despite the significant differences observed between the results of the SIR assays for the tested treatments, the overall schematic representation of the mutual relationships by PCA biplot (Figure 3B) showed clear agonisms (and convergence with BR) among all SIRs. The results of Pearson's correlation analysis support this observation (Figure 2B).

All manure-amended variants revealed increased respiration, which corresponds to previous findings [58]. It can be deduced from the results of all determined SIRs that the amendment of biochar-enriched manure promoted microbial activity in the soil, as compared to the control (Figure 3D-J). Respiration measured upon the addition of saccharides (D-glucose, D-trehalose) showed significantly increased values in $\mathrm{M}+\mathrm{B}$ and significantly decreased Tre-SIR in $\mathrm{M}+\mathrm{H}$ as compared to the other two manure-amended variants. Presumably, lower $\mathrm{C}_{\text {org }}$ in $\mathrm{M}+\mathrm{H}$ manure together with higher $\mathrm{pH}$ (Table 3) less efficiently stimulated the oxidation of primary $\mathrm{C}$-sources. Some $\mathrm{N}$-containing substrates $(N$-acetyl- $\beta$ D-glucosamine, L-lysine) led to significantly higher SIR in $\mathrm{M}+\mathrm{B}$ variant when compared to the $\mathrm{M}$, which implies that $\mathrm{M}+\mathrm{B}$ more promoted the microbial nitrifying degraders of fungal biomass (NAG is the degradation derivate of chitin). These observations are in line with our previous findings on the increased fungal abundance and higher turnover of fungal biomass, which was reported for the $M+B$ treated soil [59].

In contrast, the $\mathrm{M}+\mathrm{H}$ treatment had a negative effect on SIR in comparison to the soil amended with $\mathrm{M}+\mathrm{B}$. As such, we could not confirm that the combined addition $\mathrm{M}+\mathrm{H}$ was beneficial for soil as previously observed by [23]. The detailed evaluation of the soil basal and induced respiratory traits determined in our study revealed that the most beneficial impact on soil in terms of respiration arose from the application of manure amended with biochar, which was most likely achieved via the stimulation of fungal biomass and through the enrichment of soil with $\mathrm{C}$ and $\mathrm{N}$, and enhanced $\mathrm{C}$ and $\mathrm{N}$ mineralization [57].

\subsection{Effect of Manure and Amendments on Soil Nutrient Cycling and or Enzymatic Activities}

The amendment of soil with manure (alone or in combination) apparently stimulated mineralization of soil $C_{\text {org }}$ as evidenced by the significantly higher DHA in the M, M $+H$, 
and $\mathrm{M}+\mathrm{B}$ variants when compared to the control (Figure $1 \mathrm{~B})$. The $\mathrm{M}+\mathrm{H}$ variant showed the highest DHA, likely because it received the highest portion of the readily available $\mathrm{C}_{\text {org }}[23,60]$.

Moreover, the $\mathrm{M}+\mathrm{H}$ variant was assumed to exert the most advanced cellulose decomposition among the manure types, which preceded increased GLU. We ascribed this from the highest HA:FA ratio as a degradation process evolution indicator in the $\mathrm{M}+\mathrm{H}$ manure (Table 3). It was referred that GLU and cellulolytic microbiological functional groups were strongly correlated with the production of fulvic and humic acids [61].

We further revealed significantly increased (compared to the control) NAG in the $\mathrm{M}+\mathrm{B}$ variant, which is in line with Zhang et al. [62] and implies higher fungal abundance and its turnover in soil. Moreover, NAG is an indicator of N mineralization and nitrification, together with Ure. The Ure activity was significantly enhanced in all manure amended variants. However, the $\mathrm{M}+\mathrm{H}$ variant reached the highest value. These results suggest that $\mathrm{M}+\mathrm{H}$ addition to soil increased available and microbial $\mathrm{N}$, which is in line with previous findings $[23,60]$.

On the other hand, ARS was significantly lower in all manure-based variants as compared to the control. Therefore, the addition of manure appeared to have a rather negative effect on ARS activity, similarly to the MSW (municipal sewage water) compost that negatively impacted the activity of ARS [63]. However, the enriched manures $(\mathrm{M}+\mathrm{H}$ and $\mathrm{M}+\mathrm{B}$ ) showed significantly higher values of ARS than the M variant.

The soil phosphatase was significantly increased (as compared to the control) only in the $\mathrm{M}+\mathrm{H}$ variant, implying a positive role of Humac on P mineralization by hydrolysis of organophosphates [64]. This is in line with another study reporting that the solubility of phosphates was positively related to the humic acid content in the compost [65].

\subsection{Effect of Manure and Amendments on Physico-Chemical Properties of Soil and Plant Biomass}

The soil $\mathrm{pH}$ is controlled and driven by a number of various processes and parameters, including the composition of the soil, minerals, and soil microbial properties. In our study, only the application of $\mathrm{M}+\mathrm{H}$ significantly increased the soil $\mathrm{pH}$ (Figure 1A). On the other hand, TC contents in soil were significantly changed with the addition of $\mathrm{C}$-rich materials $(\mathrm{M}, \mathrm{M}+\mathrm{H}$, or $\mathrm{M}+\mathrm{B})$ when compared to the control soil. The highest value was reached in $\mathrm{M}+\mathrm{B}$ variant. Moreover, the Pearson correlation analysis also revealed significant positive correlations (with r values of 0.48-0.57) between Glc-SIR, NAG-SIR, Arg-SIR, and the TC content. These findings corroborate the beneficial effects of manure-based amendments on the TC content that was higher in treated $(\mathrm{M}, \mathrm{M}+\mathrm{H}, \mathrm{M}+\mathrm{B})$ variants in comparison to control (Figure 1Q), and $M+B$ reached significantly higher values than $M$. The manureinduced microbial soil activity was putatively mediated by higher nutrient availability. We ascribed this presumption from the reported observation that soil respiration was principally determined by substrate supply (which contains nutrients) rather than by the pool size of microbial biomass carbon [66]. The authors of mentioned study referred as well to specific microbial respiratory activity positively correlated with substrate (and thus nutrient) availability.

The high correlation of TN with $\mathrm{TC}(\mathrm{r}=0.92)$ documented the general increase in the availability of macronutrients in the soil treated with manure. In addition, higher TN content in the $\mathrm{M}, \mathrm{M}+\mathrm{H}$, and $\mathrm{M}+\mathrm{B}$ treatments led to the increased plant biomass in these treatments when compared to unamended soil, which corresponds with the previously reported beneficial effects of manure and organic matter co-application on soil fertility and plant growth $[23,60,67-69]$. On the other hand, the soil TN content moderately negatively correlated with $\mathrm{C}: \mathrm{N}(\mathrm{r}=-0.61)$. Therefore, we presumed higher rate of both $\mathrm{C}$ and $\mathrm{N}$ sequestration, and moderate nitrification (low $\mathrm{C}: \mathrm{N}$ ratio is assumed to cause rapid release of $\mathrm{N}$ into the soil in the form of inorganic $\mathrm{N}$ compounds such as nitrates) in the variants, which concurrently exerted the higher TC and dry AGB. 


\section{Conclusions}

The results suggested that all matured (fermented and enriched) manures differed in their physico-chemical characteristics, microbial composition, and nutrient contents as compared to the control. In the pot experiment, the soil respiration increased due to soil amendment with either manure or enriched manures. The activities of enzymes related to $\mathrm{N}$ and $\mathrm{P}$ mineralization (urease, $N$-acetyl- $\beta$-D-glucosaminidase, phosphatase) were enhanced in $\mathrm{M}+\mathrm{H}$ and $\mathrm{M}+\mathrm{B}$ variants. However, some parameters, such as arylsulfatase, decreased due to added manures. Altogether, there were several indices of the beneficial effects of enriched manures, which also translated into apparently increased plant dry biomass, especially in the case of the $\mathrm{M}+\mathrm{H}$ variant. Following our results, we may conclude that amending manure with biochar and humic acids before maturation may provide several benefits, induce positive changes in soil when applied, and ultimately support soil fertility and plant growth. However, in order to maximize the assumed synergic effects, the role of biochar and humic substances for the quality of manure and soil needs to be further studied.

Author Contributions: Conceptualization, T.H., J.H. and M.B.; methodology, T.H., J.H. and M.B.; software, T.H., T.B.; validation, M.B., T.H. and J.K.; formal analysis, O.L., T.B.; investigation, J.H., J.K., A.M. and M.B.; resources, O.L., M.R. and A.K.; data curation, T.H., M.R. and O.L.; writing-original draft preparation, T.H., L.B., J.H.; writing-review and editing, T.H., J.H., L.B., J.K., A.M. and M.B.; visualization, T.H. and A.K.; supervision, M.R., M.B.; project administration, M.B., A.K.; funding acquisition, M.B., A.K. All authors have read and agreed to the published version of the manuscript.

Funding: The work was supported by the project of the Technology Agency of the Czech Republic TH03030319, and by the Ministry of Education, Youth and Sports of the Czech Republic, grant number FCH-S-21-7398.

Data Availability Statement: The data presented in this study are available on request from the corresponding author.

Conflicts of Interest: The authors declare no conflict of interest.

\section{References}

1. McBratney, A.; Field, D.J.; Koch, A. The dimensions of soil security. Geoderma 2014, 213, 203-213. [CrossRef]

2. Ghani, A.; Dexter, M.; Perrott, K.W. Hot-water extractable carbon in soils: A sensitive measurement for determining impacts of fertilisation, grazing and cultivation. Soil Biol. Biochem. 2003, 35, 1231-1243. [CrossRef]

3. Hammerschmiedt, T.; Holatko, J.; Pecina, V.; Huska, D.; Latal, O.; Kintl, A.; Radziemska, M.; Muhammad, S.; Gusiatin, Z.M.; Kolackova, M.; et al. Assessing the potential of biochar aged by humic substances to enhance plant growth and soil biological activity. Chem. Biol. Technol. Agric. 2021, 8, 46. [CrossRef]

4. Mustafa, A.; Minggang, X.; Shah, S.A.; Abrar, M.M.; Nan, S.; Baoren, W.; Zejiang, C.; Saeed, Q.; Naveed, M.; Mehmood, K.; et al. Soil aggregation and soil aggregate stability regulate organic carbon and nitrogen storage in a red soil of southern China. J. Environ. Manag. 2020, 270, 110894. [CrossRef] [PubMed]

5. Mustafa, A.; Hu, X.; Abrar, M.M.; Shah, S.A.A.; Nan, S.; Saeed, Q.; Kamran, M.; Naveed, M.; Conde-Cid, M.; Hongjun, G.; et al. Long-term fertilization enhanced carbon mineralization and maize biomass through physical protection of organic carbon in fractions under continuous maize cropping. Appl. Soil Ecol. 2021, 165, 103971. [CrossRef]

6. Szogi, A.A.; Takata, V.H.; Shumaker, P.D. Chemical extraction of phosphorus from dairy manure and utilization of recovered manure solids. Agronomy 2020, 10, 15. [CrossRef]

7. Lendelová, J.; Žitňák, M.; Bošanský, M.; Simko, M.; Piterka, P. Testing of property changes in recycled bedding for dairy cows. Res. Agric. Eng. 2016, 62, S44-S52. [CrossRef]

8. Banik, C.; Koziel, J.A.; De, M.; Bonds, D.; Chen, B.; Singh, A.; Licht, M.A. Biochar-Swine Manure Impact on Soil Nutrients and Carbon Under Controlled Leaching Experiment Using a Midwestern Mollisols. Front. Environ. Sci. 2021, 9, 609621. [CrossRef]

9. Lima, J.R.; Goes, M.D.; Hammecker, C.; Antonino, A.C.; Medeiros, É.V.; Sampaio, E.V.; Leite, M.C.; Silva, V.P.; de Souza, E.S.; Souza, R. Effects of Poultry Manure and Biochar on Acrisol Soil Properties and Yield of Common Bean. A Short-Term Field Experiment. Agriculture 2021, 11, 290. [CrossRef]

10. Lehmann, J.; Gaunt, J.; Rondon, M. Bio-char sequestration in terrestrial ecosystems-A review. Mitig. Adapt. Strat. Glob. Chang. 2006, 11, 403-427. [CrossRef]

11. Kizito, S.; Wu, S.; Kirui, W.K.; Lei, M.; Lu, Q.; Bah, H.; Dong, R. Evaluation of slow pyrolyzed wood and rice husks biochar for adsorption of ammonium nitrogen from piggery manure anaerobic digestate slurry. Sci. Total Environ. 2015, 505, 102-112. [CrossRef] [PubMed] 
12. Lehmann, J.; Rillig, M.C.; Thies, J.; Masiello, C.A.; Hockaday, W.C.; Crowley, D. Biochar effects on soil biota-a review. Soil Biol. Biochem. 2011, 43, 1812-1836. [CrossRef]

13. Wei, Z.; Wang, J.J.; Fultz, L.M.; White, P.; Jeong, C. Application of biochar in estrogen hormone-contaminated and manure-affected soils: Impact on soil respiration, microbial community and enzyme activity. Chemosphere 2021, 270, 128625. [CrossRef] [PubMed]

14. Zhang, Y.L.; Chen, L.J.; Zhang, Y.G.; Wu, Z.J.; Ma, X.Z.; Yang, X.Z. Examining the effects of biochar application on soil phosphorus levels and phosphatase activities with visible and fluorescence spectroscopy. Guang Pu Xue Yu Guang Pu Fen Xi 2016, 36, 2325-2329.

15. Hagemann, N.; Subdiaga, E.; Orsetti, S.; de la Rosa, J.M.; Knicker, H.; Schmidt, H.-P.; Kappler, A.; Behrens, S. Effect of biochar amendment on compost organic matter composition following aerobic composting of manure. Sci. Total Environ. 2018, 613-614, 20-29. [CrossRef]

16. Czekała, W.; Malińska, K.; Cáceres, R.; Janczak, D.; Dach, J.; Lewicki, A. Co-composting of poultry manure mixtures amended with biochar-The effect of biochar on temperature and C-CO $\mathrm{CO}_{2}$ emission. Bioresour. Technol. 2016, 200, 921-927. [CrossRef]

17. He, X.; Yin, H.; Sun, X.; Han, L.; Huang, G. Effect of different particle-size biochar on methane emissions during pig manure/wheat straw aerobic composting: Insights into pore characterization and microbial mechanisms. Bioresour. Technol. 2018, 268, 633-637. [CrossRef]

18. Brtnicky, M.; Datta, R.; Holatko, J.; Bielska, L.; Gusiatin, Z.M.; Kucerik, J.; Hammerschmiedt, T.; Danish, S.; Radziemska, M.; Mravcova, L.; et al. A critical review of the possible adverse effects of biochar in the soil environment. Sci. Total Environ. 2021, 796, 148756. [CrossRef]

19. Nardi, S.; Schiavon, M.; Francioso, O. Chemical Structure and Biological Activity of Humic Substances Define Their Role as Plant Growth Promoters. Molecules 2021, 26, 2256. [CrossRef]

20. Peña-Méndez, E.M.; Havel, J.; Patočka, J. Humic substances-compounds of still unknown structure: Applications in agriculture, industry, environment, and biomedicine. J. Appl. Biomed. 2005, 3, 13-24. [CrossRef]

21. Sootahar, M.K.; Zeng, X.; Wang, Y.; Su, S.; Soothar, P.; Bai, L.; Kumar, M.; Zhang, Y.; Mustafa, A.; Ye, N. The Short-Term Effects of Mineral-and Plant-Derived Fulvic Acids on Some Selected Soil Properties: Improvement in the Growth, Yield, and Mineral Nutritional Status of Wheat (Triticum aestivum L.) under Soils of Contrasting Textures. Plants 2020, 9, 205. [CrossRef] [PubMed]

22. Albiach, R.; Canet, R.; Pomares, F.; Ingelmo, F. Organic matter components and aggregate stability after the application of different amendments to a horticultural soil. Bioresour. Technol. 2001, 76, 125-129. [CrossRef]

23. Dubey, R.K.; Dubey, P.K.; Abhilash, P. Sustainable soil amendments for improving the soil quality, yield and nutrient content of Brassica juncea (L.) grown in different agroecological zones of eastern Uttar Pradesh, India. Soil Tillage Res. 2019, $195,11$. [CrossRef]

24. Wang, C.; Tu, Q.; Dong, D.; Strong, P.J.; Wang, H.; Sun, B.; Wu, W. Spectroscopic evidence for biochar amendment promoting humic acid synthesis and intensifying humification during composting. J. Hazard. Mater. 2014, 280, 409-416. [CrossRef] [PubMed]

25. Romero, C.M.; Li, C.; Owens, J.; Ribeiro, G.O.; Mcallister, T.A.; Okine, E.; Hao, X. Nutrient cycling and greenhouse gas emissions from soil amended with biochar-manure mixtures. Pedosphere 2021, 31, 289-302. [CrossRef]

26. Arif, M.; Ali, K.; Jan, M.; Shah, Z.; Jones, D.; Quilliam, R. Integration of biochar with animal manure and nitrogen for improving maize yields and soil properties in calcareous semi-arid agroecosystems. Field Crops Res. 2016, 195, 28-35. [CrossRef]

27. Foster, E.J.; Hansen, N.; Wallenstein, M.; Cotrufo, M.F. Biochar and manure amendments impact soil nutrients and microbial enzymatic activities in a semi-arid irrigated maize cropping system. Agric. Ecosyst. Environ. 2016, 233, 404-414. [CrossRef]

28. Kanwal, S.; Batool, A.; Ghufran, M.A.; Khalid, A. Effect of dairy manure derived biochar on microbial biomass carbon, soil carbon and Vitis vinifera under water stress conditions. Pak. J. Bot. 2018, 50, 1713-1718.

29. ISO 7150-1; Water Quality—Determination of Ammonium—Part 1: Manual Spectrometric Method. International Organization for Standardization: Geneva, Switzerland, 1984.

30. ISO 10390; Soil Quality-Determination of pH. International Organization for Standardization: Geneva, Switzerland, 2005.

31. ISO 10694; Soil Quality—Determination of Organic and Total Carbon after Dry Combustion (Elemental Analysis). International Organization for Standardization: Geneva, Switzerland, 1995.

32. Zbiral, J. Determination of phosphorus in calcareous soils by Mehlich 3, Mehlich 2, CAL and Egner extractants. Commun. Soil Sci. Plant Anal. 2000, 31, 3037-3048. [CrossRef]

33. ISO 14869-3; Soil Quality-Dissolution for the Determination of Total Element Content. International Organization for Standardization: Geneva, Switzerland, 2017.

34. ISO 19822; Fertilizers and Soil Conditioners-Determination of Humic and Hydrophobic Fulvic Acids Concentrations in Fertilizer Materials. International Organization for Standardization: Geneva, Switzerland, 2018.

35. Rotthauwe, J.H.; Witzel, K.P.; Liesack, W. The ammonia monooxygenase structural gene amoA as a functional marker: Molecular fine-scale analysis of natural ammonia-oxidizing populations. Appl. Environ. Microbiol. 1997, 63, 4704-4712. [CrossRef]

36. Kandeler, E.; Deiglmayr, K.; Tscherko, D.; Bru, D.; Philippot, L. Abundance of narG, nirS, nirK, and nosZ genes of denitrifying bacteria during primary successions of a glacier foreland. Appl. Environ. Microbiol. 2006, 72, 5957-5962. [CrossRef] [PubMed]

37. Food and Agriculture Organization of the United Nations. World Reference Base for Soil Resources; FAO (Food and Agriculture Organization of the United Nations): Rome, Italy, 2014.

38. ISO 13878; Soil Quality_Determination of Total Nitrogen Content by Dry Combustion (Elemental Analysis). International Organization for Standardization: Geneva, Switzerland, 1998. 
39. ISO 20130; Soil Quality-Measurement of Enzyme Activity Patterns in Soil Samples Using Colorimetric Substrates in Micro-Well Plates. International Organization for Standardization: Geneva, Switzerland, 2018.

40. Casida, L.E., Jr.; Klein, D.A.; Santoro, T. Soil dehydrogenase activity. Soil Sci. Annu. 1964, 98, 371-378. [CrossRef]

41. Campbell, C.; Chapman, S.J.; Cameron, C.M.; Davidson, M.S.; Potts, J.M. A rapid microtiter plate method to measure carbon dioxide evolved from carbon substrate amendments so as to determine the physiological profiles of soil microbial communities by using whole soil. Appl. Environ. Microbiol. 2003, 69, 3593-3599. [CrossRef] [PubMed]

42. Hinkle, D.E.; Wiersma, W.; Jurs, S.G. Applied Statistics for the Behavioral Sciences; Houghton Mifflin: Boston, MA, USA, 2003.

43. Jiang, T.; Schuchardt, F.; Li, G.; Guo, R.; Zhao, Y. Effect of C/N ratio, aeration rate and moisture content on ammonia and greenhouse gas emission during the composting. J. Environ. Sci. 2011, 23, 1754-1760. [CrossRef]

44. Burt, C.D.; Cabrera, M.L.; Rothrock, M.J., Jr.; Kissel, D.E. Urea Hydrolysis and Calcium Carbonate Precipitation in GypsumAmended Broiler Litter. J. Environ. Qual. 2018, 47, 162-169. [CrossRef] [PubMed]

45. Zhang, J.; Lü, F.; Shao, L.; He, P. The use of biochar-amended composting to improve the humification and degradation of sewage sludge. Bioresour. Technol. 2014, 168, 252-258. [CrossRef] [PubMed]

46. Kipton, H.; Powell, J.; Town, R.M. Solubility and fractionation of humic acid; effect of $\mathrm{pH}$ and ionic medium. Anal. Chim. Acta 1992, 267, 47-54. [CrossRef]

47. Swift, R.; Posner, A. Autoxidation of humic acid under alkaline conditions. J. Soil Sci. 2006, 23, 381-393. [CrossRef]

48. Bi, Z.; Takekawa, M.; Park, G.; Soda, S.; Zhou, J.; Qiao, S.; Ike, M. Effects of the c/n ratio and bacterial populations on nitrogen removal in the simultaneous anammox and heterotrophic denitrification process: Mathematic modeling and batch experiments. Chem. Eng. J. 2015, 280, 606-613. [CrossRef]

49. Paul, J.W.; Beauchamp, E.G. Effect of carbon constituents in manure on denitrification in soil. Can. J. Soil Sci. 1989, 69, 49-61. [CrossRef]

50. Dlamini, J.C.; Chadwick, D.; Hawkins, J.M.B.; Martinez, J.; Scholefield, D.; Ma, Y.; Cárdenas, L.M. Evaluating the potential of different carbon sources to promote denitrification. J. Agric. Sci. 2020, 158, 194-205. [CrossRef]

51. Sarkhot, D.V.; Berhe, A.A.; Ghezzehei, T.A. Impact of biochar enriched with dairy manure effluent on carbon and nitrogen dynamics. J. Environ. Qual. 2012, 41, 1107-1114. [CrossRef] [PubMed]

52. Agyarko-Mintah, E.; Cowie, A.; Singh, B.P.; Joseph, S.; Van Zwieten, L.; Cowie, A.; Harden, S.; Smillie, R. Biochar increases nitrogen retention and lowers greenhouse gas emissions when added to composting poultry litter. Waste Manag. 2017, 61, 138-149. [CrossRef] [PubMed]

53. Violante, A.; Pigna, M.; Ricciardella, M.; Gianfreda, L. Adsorption of phosphate on variable charge minerals and soils as affected by organic and inorganic ligands. In Soil Mineral-Organic Matter-Microorganism Interactions and Ecosystem Health; Vol 28A: Dynamics, Mobility and Transformation of Pollutants and Nutrients; Violante, A., Huang, P.M., Bollag, J.M., Gianfreda, L., Eds.; Elsevier Science BV: Amsterdam, The Netherlands, 2002; Volume 28A, pp. 279-295.

54. Luo, Y.; Xie, K.; Zhang, K.; Shen, S.; Wang, F. Research progress on removal of phosphate from aqueous solution by biochar and its metal modified materials. Huanjing Huaxue-Environ. Chem. 2020, 39, 2175-2186. [CrossRef]

55. Liu, L.; Ji, M.; Wang, F.; Tian, Z.; Wang, T.; Wang, S.; Wang, S.; Yan, Z. Insight into the short-term effect of fulvic acid on nitrogen removal performance and N-acylated-L-homoserine lactones (AHLs) release in the anammox system. Sci. Total Environ. 2020 704, 7. [CrossRef]

56. Chakraborty, A.; Chakrabarti, K.; Chakraborty, A.; Ghosh, S. Effect of long-term fertilizers and manure application on microbial biomass and microbial activity of a tropical agricultural soil. Biol. Fertil. Soils 2011, 47, 227-233. [CrossRef]

57. Holatko, J.; Hammerschmiedt, T.; Datta, R.; Baltazar, T.; Kintl, A.; Latal, O.; Pecina, V.; Sarec, P.; Novak, P.; Balakova, L.; et al Humic Acid Mitigates the Negative Effects of High Rates of Biochar Application on Microbial Activity. Sustainability 2020, 12, 9524. [CrossRef]

58. Ros, M.; Klammer, S.; Knapp, B.; Aichberger, K.; Insam, H. Long-term effects of compost amendment of soil on functional and structural diversity and microbial activity. Soil Use Manag. 2006, 22, 209-218. [CrossRef]

59. Brtnicky, M.; Dokulilova, T.; Holatko, J.; Pecina, V.; Kintl, A.; Latal, O.; Vyhnanek, T.; Prichystalova, J.; Datta, R. Long-term effects of biochar-based organic amendments on soil microbial parameters. Agronomy 2019, 9, 747. [CrossRef]

60. Zhang, L.; Sun, X.-Y.; Tian, Y.; Gong, X.-Q. Biochar and humic acid amendments improve the quality of composted green waste as a growth medium for the ornamental plant Calathea insignis. Sci. Hortic. 2014, 176, 70-78. [CrossRef]

61. Salgado, M.M.M.; Blu, R.O.; Janssens, M.; Fincheira, P. Grape pomace compost as a source of organic matter: Evolution of quality parameters to evaluate maturity and stability. J. Clean. Prod. 2019, 216, 56-63. [CrossRef]

62. Zhang, X.; Dong, W.; Dai, X.; Schaeffer, S.; Yang, F.; Radosevich, M.; Xu, L.; Liu, X.; Sun, X. Responses of absolute and specific soil enzyme activities to long term additions of organic and mineral fertilizer. Sci. Total Environ. 2015, 536, 59-67. [CrossRef] [PubMed]

63. Albiach, R.; Canet, R.; Pomares, F.; Ingelmo, F. Microbial biomass content and enzymatic activities after the application of organic amendments to a horticultural soil. Bioresour. Technol. 2000, 75, 43-48. [CrossRef]

64. Jin, Y.; Liang, X.; He, M.; Liu, Y.; Tian, G.; Shi, J. Manure biochar influence upon soil properties, phosphorus distribution and phosphatase activities: A microcosm incubation study. Chemosphere 2015, 142, 128-135. [CrossRef] [PubMed] 
65. Busato, J.G.; Papa, G.; Canellas, L.P.; Adani, F.; de Oliveira, A.L.; Leão, T.P. Phosphatase activity and its relationship with physical and chemical parameters during vermicomposting of filter cake and cattle manure. J. Sci. Food Agric. 2016, 96, 1223-1230. [CrossRef]

66. Wang, W.J.; Dalal, R.C.; Moody, P.W.; Smith, C.J. Relationships of soil respiration to microbial biomass, substrate availability and clay content. Soil Biol. Biochem. 2003, 35, 273-284. [CrossRef]

67. Troy, S.M.; Lawlor, P.G.; Flynn, C.J.O.; Healy, M.G. Impact of biochar addition to soil on greenhouse gas emissions following pig manure application. Soil Biol. Biochem. 2013, 60, 173-181. [CrossRef]

68. Ippolito, J.A.; Stromberger, M.E.; Lentz, R.D.; Dungan, R.S. Hardwood biochar and manure co-application to a calcareous soil. Chemosphere 2016, 142, 84-91. [CrossRef]

69. Cao, Y.; Bai, M.; Han, B.; Impraim, R.; Butterly, C.; Hu, H.; He, J.; Chen, D. Enhanced nitrogen retention by lignite during poultry litter composting. J. Clean. Prod. 2020, 277, 10. [CrossRef] 